\title{
Recent Advancement on Solar Photovoltaic Energy Generation System Special Reference to Shading Condition- A Review
}

\author{
Fahad Saleh M. Abdallah' ${ }^{1}$, M. N. Abdullah ${ }^{2}$, Ismail Musirin ${ }^{3}$, Ahmed M. Elshamy $^{4}$ \\ ${ }^{1,2}$ Green and Sustainable Energy (GSEnergy) Focus Group, Faculty of Electrical and Electronic Engineering, \\ Universiti Tun Hussein Onn Malaysia, Malaysia, he170029@ siswa.uthm.edu.my ,mnoor@uthm.edu.my \\ ${ }^{3}$ Faculty of Engineering, Universiti Teknologi MARA, Malaysia, ismailbm @elect.itm.edu.my \\ ${ }^{4}$ Faculty of Engineering, Minia University, Egypt, a.alshamy@egov.fujairah.ae
}

\begin{abstract}
Design of a Solar PV Energy Generation to harness the optimum solar energy has been a big challenge among the researcher. It is quite essential to review the latest all the available technique, their advantages and disadvantages, prior to designing a new Solar PV Energy Generation system. In present paper a detail discussion is presented on various maximum power points tracking algorithms employed on Photovoltaic Energy generation system under shading condition. We have covered the various algorithms, PV modelling techniques, PV array configuration, monitoring system etc. up to till date. Impact of shading effect is reported massive on energy supply capacity. Hence, in this paper we have investigated and discussed the various type of PV module at different type of shading level. This paper provides a handy reference to undertake a mass research works on PV system in near future under shading condition.
\end{abstract}

Key words : PV Cell module, Shading condition, PV module algorithm, Maximum power point tracking (MPPT), PV Panel array

\section{INTRODUCTION}

Growing demand of energy and the life threatening health problem due to coal produced electricity make it essential to go for various green energy production techniques. Solar energy being abundantly available is the great hope for human beings to accomplish the rising need. Photovoltaic Energy generation under shading condition have a huge adverse efficiency effect [1]-[3]. It suddenly comes in our mind that how to avoid completely to the shading effect, but it is not possible. Natural phenomenon such as cloud, rain or the manmade obstruction such as high pollution or tall buildings is obviously comes in generation of energy by PV system. Even if a section of PV panel is in shade then there is a lot of differences in performance, this is due to the PV array configuration. As we know the usual configuration is the connection of number of photovoltaic cell together as a series or parallel connection [3]. Hence there is drastic reduction in final energy output of the panel even at partial shading condition. Another aspect is related to the presence of bypass diode in various ways in the configuration of PV panel. It is well known that curve of the PV cell varies on the radiation received and the temperature, here the diode allows the current flow through alternate path in the PV module. By pass diodes are used either as overlapped or non-overlapped depending on configuration, thus in the case of shaded PV panel the net output get reduced drastically as there is restriction in the direction of current flow. Many publication supported the theory of reduction of energy directly proportional to the area of shading of PV panel [8]. This finding seems reasonably accurate especially in the case of single PV cell but at the module or array level it is not exactly true as the module or array are often far from the linearity with the shaded portion [9].

Many research publications reported on various configurations to minimize the loss effect due to PV panel under shading condition [4]-[6]. Regular configuration such as series- parallel, total cross- tied, bridge -linked, etc. are been checked under shading condition with an aim to get an optimum energy output [32]. A modelling process having PV array connected in any configuration operating under uniform or partial shading is also been reported appreciating results [36].

Shading detection and tracking algorithm using the trend of slopes from each section of the curve is reported by a researcher having valuable findings for future application on artificial based technology (Global maximum GM). The hotspot detection algorithm is also proposed based on analysis of various PV array configuration, which is also been validated by simulation result by the researcher [45].

In present review work an attempt have been made by the authors to summarise with necessary details all the work done on various algorithms, PV modelling techniques, PV array configuration as well as monitoring system from earlier findings to the recent one, we have tried to present our view based on their discussions. We hope that this piece of work will be immense helpful for new research worker exploring to start a research work as well as working engineers who is in the process of fabrication of a new PV module. We have presented a chronology table of development on PV energy generation especially the papers focused on shorting out problem of shading. 
Fahad Saleh M. Abdallah et al., International Journal of Science and Advanced Information Technology, 8 (4), July - August 2019,1 - 6

\section{PV CHARACTERISTICS}

Diode model of Photoelectric cell is generally used to describe the I-V characteristics. In Figure 2.1, an equivalent circuit of a PV cell is displayed.

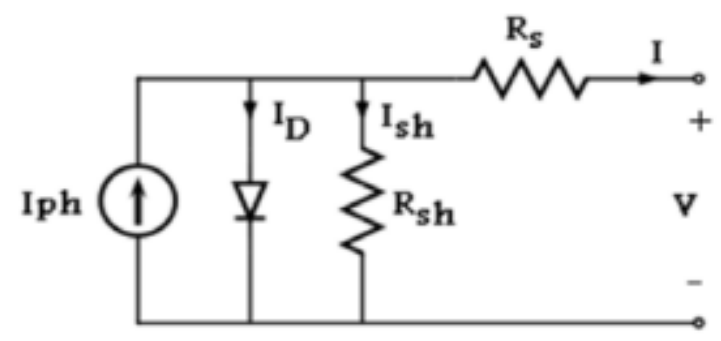

Figure 2.1: Equivalent circuit of a PV cell [7]

Here, in the Circuit

Ish - represent the shunt current in Ampere

$\mathrm{Rsh}$ - is the shunt resistance in $\mathrm{Ohm}$

Iph - is the photo current in Ampere

$\mathrm{I}_{\mathrm{D}}-$ is the diode current in Ampere

$\mathrm{Rs}-$ is the shunt resistance in $\mathrm{Ohm}$

To determine the I-V characteristics, following relation is useful [7]-

$\mathrm{Iph}=\mathrm{I}_{\mathrm{D}}+\mathrm{Ish}+\mathrm{I}$

(1)

In literatures [7]-[9], the shading effect on output power is reported. However, in conventional models of PV modules, discussion on open circuit voltage, short circuit current, and various loss sources are quite often discussed [10]-[13]. We are presenting here two curves helpful in discussion of shading first one is current verses voltage and the second one is power verses voltage [7]. These curves are shown in Figure 2.2.

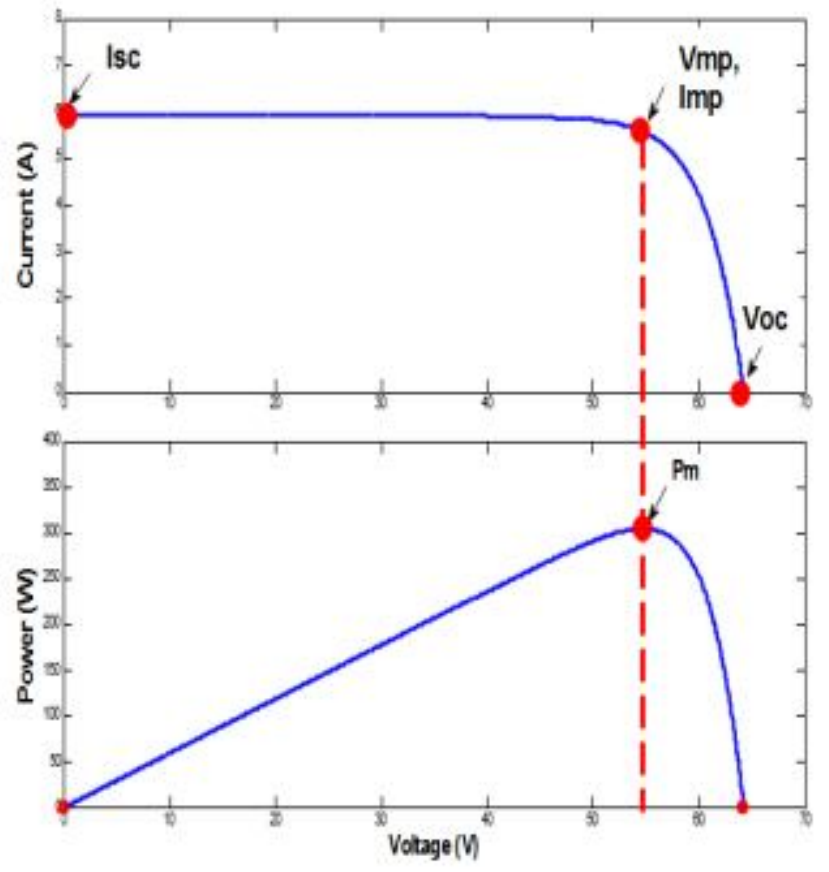

Figure 2.2: PV module I-V \& W-V curves [7].

\section{PHOTOVOLTAIC ARRAY-MODELLING}

Various Modelling of PV cell has been attempted by authors [14]-[20], to overcome the shading problem. PV module having single diode model and a bypass diode is found to have many advantages to boost the efficiency [14]. The equivalent circuit diagram of the model is placed as Figure 3.1. Introduction of sub-array (SA) in the model make the concept more energy boosting which reflects in terms of the SA

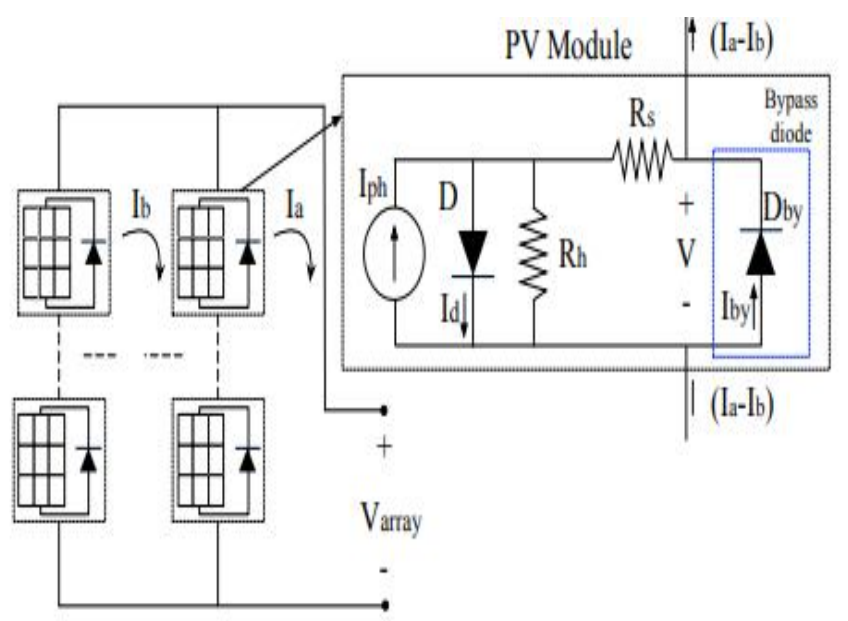

current.

Figure 3.1: PV model having single diode and by-pass filter diode [15].

Author [15], has applied Kirchhoff's current and voltage law to establish a relation among the module voltage $(\mathrm{V})$, and the mesh current at the right (Ia) and at the left (Ib) of the PV model. The equation representing the relation among the various parameters of PV model is given below as equation 1 .

$$
\begin{aligned}
\left(I_{a}-I_{b}\right)= & I_{\text {ph }}-I_{\text {sat }} \cdot\left(\exp \left(\frac{V+\left(I_{a}-I_{b}-I_{b y}\right) \cdot R_{s}}{N_{s} \cdot \beta}\right)-1\right) \\
& +I_{\text {sat }, \text { by }} \cdot\left(\exp \left(\frac{-V}{\beta_{b y}}\right)-1\right) .
\end{aligned}
$$

Where,

Isat - be the saturation current of PV module diode $\mathrm{Ns}-$ be the number of series connected cell in the module $\beta=\mathrm{n} . \mathrm{k} . \mathrm{Tpv} / \mathrm{q}$, here $\mathrm{n}$ is the ideality factor, $\mathrm{k}$ is the Boltzman constant, $\mathrm{q}$ is the charge by - represent for bypass diode.

In above equation only Iph and Isat depends on irradiance (S) and Temperature (T) while the other parameters are constant; hence this equation has found more relevancy in calculation of output power as far as the case of shading is concern. 
Fahad Saleh M. Abdallah et al., International Journal of Science and Advanced Information Technology, 8 (4), July - August 2019,1 - 6

\section{MAXIMUM POWER POINT TRACKING (MPPT) ALGORITHM UNDER SHADING CONDITION}

There are many report on various technique to tackle the shading in PV module is present [21]-[29]. These techniques are categorized under maximum power point tracking (MPPT) algorithm. A general representation of shading in a PV module is represented by a diagram shown in Figure 4.1 [21].

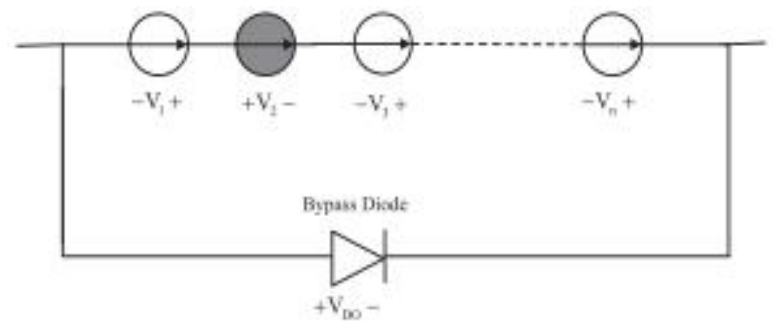

Figure 4.1: One shaded shell in bypass conduction diode diagram

In coming sub section various optimization techniques are discussed to understand the latest progress in the field of PV module in shading hindrance.

\subsection{GRAY WOLF OPTIMIZATION}

In the gray wolf optimization (GWO) simulation technique the leadership i.e. better efficiency of PV module is established by considering four types of gray wolves known by alpha $(\alpha)$, beta $(\beta)$, delta $(\lambda)$ and omega $(\omega)$. Simulation is based on attacking technique; the optimum fittest solution is found with the wolf alpha, then second with beta, after that the delta. Omega is denoted as rest of the candidate solution. Gray wolf optimization have three steps or better to say programming- hunting, chasing and tracking the prey by forming group and the encircling the prey and finally solved it by attacking. The Flow chart to represent the algorithm of GWO is displayed as Figure 4.2 [22].

Complete hunting mechanism of GWO is computed based on following two equations-

$$
\begin{aligned}
& \vec{E}=\left|\vec{C} \cdot \overrightarrow{X_{P}}(t)-\overrightarrow{X_{P}}(t)\right| \vec{E}=\left|\vec{C} \cdot \overrightarrow{X_{\rho}}(t)-\overrightarrow{X_{p}}(t)\right| \\
& \vec{X}(t+1)=\overrightarrow{X_{P}}(t)-\vec{F} \cdot \vec{E}
\end{aligned}
$$

Here $t$ represents for current iteration; E,F and C represents the coefficient vector. $\mathrm{Xp}$ is the hunting prey and $\mathrm{X}$ represent the position vector for the gray wolf.

\subsection{Ant colony optimization}

Ant colony optimization (ACO) is a probabilistic algorithm applied to tackle the shading problem by many authors [23]-[24]. Idea of food searching behaviour of ants is applied here to get the optimum power output. It provides the optimized duty cycle after sensing the output power in PV module. Optimized duty cycle is further applied to the convertor.

\subsection{Artificial bee colony algorithm}

Artificial bee Colony (ABC) algorithm is considered as a simple optimization technique in which a few controlled parameters are used ; here the important thing is that algorithm convergence criterion are independent of the initial condition of the system. It is a swarm based algorithm capable of solving multidimensional and multimodal optimization problem efficiently [25]-[26].

\subsection{Swarm optimization}

The deterministic particle swarm optimization (DPSO) is an improved PV module shading condition algorithm. It is a known to have better improved algorithm having capability to contribute in tracking and overcome the problem related to shading. If a change in the duty cycle for two successive counts is low, then DPSO is helpful in optimization in final output and making the PV module much efficient under shading condition [27]-[37].

\section{MPPT AND HOT SPOT DETECTION}

Many failures in MMPT are a result of the Hot-Spot phenomenon [38]-[47]. This is a occurrence in which defective cell turn out to be hot when shadow take place on the cell. This happening become basis for breaking of the cell or a fire. While there is a predictable method for measuring temperature, such as using an infrared camera, for the purpose of checking for a Hot-Spot, the method necessitate a lot of time and endeavour. A range of studies have been performed about Hot-Spot [42]-[44]. For example, there is a report about Hot-Spot detection method using AC parameter categorization of PV module [45]. However, occurring Hot-Spot cannot be monitored on these studies while PV system is operating. Authors developed Hot-Spot detection method to module before installation using projector [46]-[47]. However, Hot-Spot always occurs because of various factors even if the module is normal at checking for a Hot-Spot. Various models are available on study to manage the problem of hot spot.

\subsection{Hot Spot shading detection}

The reported Hot-Spot shading monitoring system make use of slope of I-V characteristic of PV module in region of high voltage part. It has been reported that current has a negative 
Fahad Saleh M. Abdallah et al., International Journal of Science and Advanced Information Technology, 8 (4), July - August 2019,1 - 6

slope to the voltage in area of high voltage side in the case of Hot-Spot module [48]-[55]. It has been further reported that the current difference between the two points V1 and V2 volts and the short circuit current value determination helps in monitoring of hot spot shading detection and prevention of any damage.

\section{CONCLUSIONS}

Problem related to Solar PV Energy generation under shading condition is discussed elaborately in this paper. It is well known that shading condition has a huge adverse efficiency effect. Various PV array configuration to overcome the problem of shading is covered in this paper. It has been found through various reports that there is drastic reduction in final energy output of the panel even at partial shading condition. Another aspect found is related to the presence of bypass diode in various ways in the configuration of PV panel. It is well known that curve of the PV cell varies on the radiation received and the temperature, here the diode allows the current flow through alternate path in the PV module. Finding seems reasonably accurate especially in the case of single PV cell but at the module or array level it is not exactly true as the module or array are often far from the linearity with the shaded portion. It has been found that the regular configuration such as series- parallel, total cross- tied, bridge -linked, etc. under shading condition are results in an optimum energy output. A modelling process having PV array connected in any configuration operating under uniform or partial shading is also been discussed in this paper. Shading detection and tracking algorithm using the trend of slopes from each section of the curve is reported and discussed in the paper. Reports on various technique to tackle the shading in PV module is present in this paper. These techniques are categorized under maximum power point tracking (MPPT) algorithm. Many failures in MMPT are a result of the Hot-Spot phenomenon.

\section{REFERENCES}

1. Winston, D. P., Kumaravel, S., Kumar, B. P., and Devakirubakaran, S. "Performance improvement of solar PV array topologies during various partial shading conditions," Solar Energy, 196. 228-242.2020.

2. Trzmiel, G., Głuchy, D., and Kurz, D. "The impact of shading on the exploitation of photovoltaic installations," Renewable Energy,153. 2020.

3. Review of Recent Advances of Shading Effect on PV Solar Cells Generation Qasim A. Alabdali1 , Abdulwahab M. Bajawi2 , Ahmed M. Nahhas, Sustainable Energy, 2020, Vol. 8, No. 1, 1-5

4. Global Maximum Power Point Tracking under Shading Condition and Hotspot Detection Algorithms for Photovoltaic Systems Jirada Gosumbonggot $1,{ }^{*}$ and Goro Fujita 2, Energies 2019, 12, 882; doi:10.3390/en12050882.
5. "half-cell technology," solarabic, 2019. [Online]. Available:

https://solarabic.com/learn/2019/07/solar-cells-technologies-halfcut-cells -explained/.

6. Gupta, V., Sharma, M., Pachauri, R. K., and Babu, K. D. "Comprehensive review on effect of dust on solar photovoltaic system and mitigation techniques," Solar Energy, 191. 596-622. 2019.

7. Djalab, A., Bessous, N., Rezaoui, M. M., and Merzouk, I. "Study of the Effects of Partial Shading on PV Array," International Conference on Communications and Electrical Engineering (ICCEE), 1-5. IEEE. 2018.

8. Babatunde, A. A., Abbasoglu, S., and Senol, M. "Analysis of the impact of dust, tilt angle and orientation on performance of PV Plants," Renewable and Sustainable Energy Reviews, 90, 1017-1026. 2018.

9. Pillai, D.S.; Rajasekar, N. A comprehensive review on protection challenges and fault diagnosis in PV systems. Renew. Sustain. Energy Rev. 2018, 91, 18-40.

10. Olalla, C.; Hasan, M.; Deline, C.; Maksimovi'c, D. Mitigation of Hot-Spots in Photovoltaic Systems using Distributed Power Electronics. Energies 2018, 11, 726.

11. Yang, S.; Itako, K.; Kudoh, T.; Koh, K.; Ge, Q. Monitoring and Suppression of the Typical Hot-Spot Phenomenon Resulting From Low-Resistance Defects in a PV String. IEEE J. Photovolt. 2018, 8, 1809-1817.

12. Gosumbonggot, J. Partial Shading and Global Maximum Power Point Detection Enhancing MPPT for Photovoltaic Systems Operated in Shading Condition. In Proceedings of the 2018 53rd International Universities Power Engineering Conference (UPEC), Glasgow, UK, 4-7 September 2018.

13. Islam, H.; Mekhilef, S.; Shad, N.B.M.; Soon, T.K.; Seyedmahmousian, M.; Horan, B.; Stojcevski, A. Performance Evaluation of Maximum Power Point Tracking Approaches and Photovoltaic Systems. Energies 2018, 11, 365.

14. Bastidas-Rodriguez, J.D.; Trejos-Grisales, L.A.; Gonzalez-Montoya, D.; Ramos-Paja, C.A.; Petrone, G.; Spagnuolo, G. General modeling procedure for photovoltaic arrays. Electr. Power Syst. Res. 2018, 155, 67-79.

15. Daniel Gonzalez Montoya , Juan David Bastidas-Rodriguez , Luz Adriana Trejos-Grisales , Carlos Andres Ramos-Paja , Giovanni Petrone and Giovanni Spagnuolo, A Procedure for Modeling Photovoltaic Arrays under Any Configuration and Shading Conditions, Energies 2018, 11, 767; doi:10.3390/en11040767

16. Mishra, N.; Yadav, A.; Pachauri, R.; Chauhan, Y.; Yadav, V. Performance enhancement of PV system using proposed array topologies under various shadow patterns. Solar Energy 2017, 157, 641-656.

17. S.K. Sinha, S. Yadav, P.M. Raole, Sol-gel followed by urea-acetone spherodization for preparation of lithium titanate ceramics pebbles and preliminary 
Fahad Saleh M. Abdallah et al., International Journal of Science and Advanced Information Technology, 8 (4), July - August 2019 , 1 - 6

characterization, Fusion Engineering and Design, Volume 113, 2016, 146-150

18. Alsafasfeh, M.; Abdel-Qader, I.; Bazuin, B. Fault detection in photovoltaic system using SLIC and thermal images. In Proceedings of the 2017 8th International Conference on Information Technology (ICIT), Amman, Jordan, 17-18 May 2017; pp. 672-676.

19. Karim D. Backstepping sliding mode control for maximum power point tracking of a photovoltaic system. Electr. Power Syst. Res. 2017, 143, 182-188.

20. Alivarani Mohapatraa, $\square$, Byamakesh Nayaka , Priti Dasa, Kanungo Barada Mohanty, A review on MPPT techniques of PV system under partial shading condition, Renewable and Sustainable Energy Reviews 80 (2017) 854-867

21. Ahmed, J. An accurate method for MPPT algorithm to detect the Partial shading Occurrence in a PV system. IEEE Trans. Ind. Inform. 2017, 13.

22. Mohanty S, Subudhi B, Ray PK. A new MPPT design using grey Wolf optimization technique for photovoltaic system under partial shading conditions. IEEE Trans Sustain Energy 2016;7:181-8.

23. Jiang LL, Maskell DL, Patra JC. A novel ant colony optimization-based maximum power point tracking for photovoltaic systems under partially shaded conditions. Energy Build 2013;58:227-36

24. Jiang LL, Maskell DL. A uniform implementation scheme for evolutionary optimization algorithms and the experimental implementation of an ACO based MPPT for PV systems under partial shading. In: Proceedings of the IEEE symp comput intell appl smart grid (CIASG 2014); 2014. p. 1-8.

25. Sundareswaran K, Sankar P, Nayak PSR, Simon SP, Palani S. Enhanced energy output from a PV system under partial shaded conditions through artificial bee colony. IEEE Trans Sustain Energy 2015;6:198-209

26. soufyane Benyoucef A, Chouder A, Kara K, Silvestre S, sahed OA. Artificial bee colony based algorithm for maximum power point tracking (MPPT) for PV systems operating under partial shaded conditions. Appl Soft Comput 2015;32:38-48.

27. Karami, N., Moubayed, N., and Outbib, R. "General review and classification of different MPPT Techniques," Renewable and Sustainable Energy Reviews, 68. 1-18.2017.

28. Mehiri, A., Hamid, A. K., and Almazrouei, S. "The Effect of Shading with Different PV Array Configurations on the GridConnected PV System,” 2017 International Renewable and Sustainable Energy Conference (IRSEC), 1-6. IEEE. 2017.

29. Sona Kumari, R.K.Chaudhary, S.K,.Sinha, Preparation of $\mathrm{PbTi}$ 0.8-xTb0.2MgxO3 nano ceramics by high energy ball milling and its characterization, Digest $\mathrm{Jr}$ of nanometer.and Biostructure, 13 (4) Oct-Dec (2018)

30. Belhaouas, N., Cheikh, M. S. A., Agathoklis, P., Oularbi, M. R., Amrouche, B., Sedraoui, K., and Djilali, N. "PV array power output maximization under partial shading using new shifted PV array arrangements," Applied Energy, 187. 326-337.2017

31. International Energy Agency (IEA). Snapshot of Global PV Markets 2016; Technical Report; International Energy Agency: Paris, France, 2017.

32. Bassam, A.; May Tzuc, O.; Escalante Soberanis, M.; Ricalde, L.J.; Cruz, B. Temperature Estimation for Photovoltaic Array Using an Adaptive Neuro Fuzzy Inference System. Sustainability 2017, 9, 1399.

33. Orioli, A.; Gangi, A.D. A Criterion for Rating the Usability and Accuracy of the One-Diode Models for Photovoltaic Modules. Energies 2016, 9, 427.

34. Mishra, N.; Yadav, A.; Pachauri, R.; Chauhan, Y.; Yadav, V. Performance enhancement of PV system using proposed array topologies under various shadow patterns. Solar Energy 2017, 157, 641-656.

35. Sona Kumari, S.K. Sinha, R.K. Chaudhary, Preparation and Characterization of $\mathrm{Ca}+2$ modified PbTi03 ceramics by HEBM technique, Materials Today: Proceedings, Volume 4, Issue 4, Part E, 2017, 5715-5720,

36. Rabinovici, R.; Dagan, T. Assessment of Solar Irradiance in Large-Scale Photovoltaic Fields by Means of Video Processing. In Proceedings of the 2012 IEEE 27th Convention of Electrical and Electronics Engineers in Israel, Eilat, Israel, 14-17 November 2012; pp. 1-5.

37. Bassam, A.; May Tzuc, O.; Escalante Soberanis, M.; Ricalde, L.J.; Cruz, B. Temperature Estimation for Photovoltaic Array Using an Adaptive Neuro Fuzzy Inference System. Sustainability 2017, 9, 1399.

38. Li, Y.; Ding, D.; Liu, C.; Wang, C. A pixel-based approach to estimation of solar energy potential on building roofs. Energy Build. 2016, 129, 563-573.

39. Nocedal, J.; Wright, S.J. Numerical Optimization, 2nd ed.; Springer: Berlin, Germany, 2006. 21. Ko, S.W.; Ju, Y.C.; Hwang, H.M.; So, J.H.; Jung, Y.S.; Song, H.; Kim, S.; Kang, G.H. Electric and thermal characteristics of photovoltaic modules under partial shading and with a damaged bypass diode. Energy 2017, 128, 233-243.

40. ERDM Solar. Datasheet ERDM Solar; ERDM Solar: San Andrés Tuxtla, Mexico, 2017. 23. Petrone, G.; Ramos-Paja, C. Modeling of photovoltaic fields in mismatched conditions for energy yield evaluations. Electr. Power Syst. Res. 2011, 81, 1003-1013.

41. Bastidas, J.D.; Franco, E.; Petrone, G.; Ramos-Paja, C.A.; Spagnuolo, G. A model of photovoltaic fields in mismatching conditions featuring an improved calculation speed. Electr. Power Syst. Res. 2013, 96, 81-90.

42. Picault, D.; Raison, B.; Bacha, S.; de la Casa, J.; Aguilera, J. Forecasting photovoltaic array power production subject to mismatch losses. Solar Energy 2010, 84, 1301-1309.

43. Ishaque, K.; Salam, Z.; Taheri, H.; Syafaruddin, S. Modeling and simulation of photovoltaic (PV) system during partial shading based on a two-diode model. Simul. Model. Pract. Theory 2011, 19, 1613-1626. 
Fahad Saleh M. Abdallah et al., International Journal of Science and Advanced Information Technology, 8 (4), July - August 2019,1 - 6

44. Bidram A, Davoudi A, Balog RS. Control and circuit techniques to mitigate partial shading effects in photovoltaic arrays. IEEE J Photovolt 2012;2:532-46. http:// dx.doi.org/10.1109/JPHOTOV.2012.2202879.

45. Ishaque K, Salam Z. A review of maximum power point tracking techniques of PV system for uniform insolation and partial shading condition. Renew Sustain Energy Rev 2013;19:475-88 http://dx.doi.org/10.1016/j.rser.2012.11.032.

46. Liu L, Meng X, Liu C. A review of maximum power point tracking methods of PV power system at uniform and partial shading. Renew Sustain Energy Rev 2016;53:1500-7. http://dx.doi.org/10.1016/j.rser.2015.09.065.

47. Rajesh R, Carolin Mabel M. A comprehensive review of photovoltaic systems. Renew Sustain Energy Rev 2015;51:231-48. http://dx.doi.org/10.1016/ j.rser.2015.06.006.

48. Mohanty S, Subudhi B, Ray PK. A new MPPT design using grey Wolf optimization technique for photovoltaic system under partial shading conditions. IEEE Trans Sustain Energy 2016;7:181-8. http://dx.doi.org/10.1109/TSTE.2015.2482120.

49. Sundareswaran K, Peddapati S, Palani S. MPPT of PV systems under partial shaded conditions through a colony of flashing fireflies. IEEE Trans Energy Convers 2014;29:463-72.

http://dx.doi.org/10.1109/TEC.2014.2298237.

50. Safarudin YM, Priyadi A, Purnomo MH, Pujiantara M. Maximum power point tracking algorithm for photovoltaic system under partial shaded condition by means updating $\beta$ firefly technique. In: Proceedings of the 6th int conf inf technol electr eng (ICITEE 2014); 2014. p. 1-4. http://dx.doi.org/10.1109/ICITEED.2014. 7007942 .

51. Jiang LL, Maskell DL, Patra JC. A novel ant colony optimization-based maximum power point tracking for photovoltaic systems under partially shaded conditions. Energy Build 2013;58:227-36. http://dx.doi.org/10.1016/j.enbuild.2012.12.001.

52. S. K. Sinha, S. Kumari, R. K. Chaudhary, Studies of dielectric and piezoelectric properties of $\mathrm{PbTi} 0.8-\mathrm{x} 0.8-\mathrm{x}$ Te0.20.2GdxO3 nano ceramics prepared by high energy ball milling, Journal of Advanced DielectricsVol. 09, No. 02, 1950017 (2019)

53. Sundareswaran K, Sankar P, Nayak PSR, Simon SP, Palani S. Enhanced energy output from a PV system under partial shaded conditions through artificial bee colony. IEEE Trans Sustain Energy 2015;6:198-209. http://dx.doi.org/10.1109/ TSTE.2014.2363521.

54. Soufyane Benyoucef A, Chouder A, Kara K, Silvestre S, sahed OA. Artificial bee colony based algorithm for maximum power point tracking (MPPT) for PV systems operating under partial shaded conditions. Appl Soft Comput 2015;32:38-48 http://dx.doi.org/10.1016/j.asoc.2015.03.047.
55. Ishaque ZS K. A deterministic particle swarm optimization maximum power point tracker for photovoltaic system under partial shading condition. IEEE Trans Ind Electron 2013;60:3195-206. 